\title{
Multimedia-Assisted Learning in a Flipped Classroom: A Case Study of Autonomous Learning on EFL University Students
}

\author{
https://doi.org/10.3991/ijet.v15i24.14017 \\ Eko Aprianto ( $\left.{ }^{\bowtie}\right)$, Oikurema Purwati, Syafi’ul Anam \\ Universitas Negeri Surabaya, Surabaya, Indonesia \\ eko.17070956019@mhs.unesa.ac.id
}

\begin{abstract}
This current study aims to investigate the use of multimediaassisted learning in a flipped classroom for fostering the students' autonomous learning at EFL University. The students are encouraged to learn independently by having multimedia learning sources and they are also stimulated to find their difficulties in the learning process. Meanwhile, the teacher and students are discussing the solution from the students' difficulties during their independent learning in the classroom. The successful completion of pre-learning depends on the students' responsibilities and enthusiasms. 15 students of the English Education department were involved as the participants in this study. The data were collected through observation, questionnaire, and semi-structured interview. The finding of this study showed that a flipped classroom by using multimedia-assisted learning helps the students stimulate their autonomous learning because the students feel free to explore their creativity through an independent learning atmosphere without any tension.
\end{abstract}

Keywords-Multimedia-assisted learning, flipped classroom autonomous learning

\section{Introduction}

In the last decades, the teaching and learning process by using technology and applications have become a necessity for the teachers to respond the changes of teaching from face to face teaching learning to online teaching. The development of technology requires a change in the teaching and learning environment. Although technology does not replace existing conventional methods, its emergence will enhance the process of learning [1]. The education systems have principal responsibilities to mitigate the demands generated by the technology development. For this purpose, the system of education quality not only limited to transform the traditional method but also emphasizing the uses of technology in appropriate situations.

To achieve the target of language teaching, language teachers as well as other people who are participating in language learning, have to be able to include information and computer technology (ICT) and to explore its diversity in the 
language classroom [2]. For instance, the students of today grow up immersed in a wide range of digital devices. They may also have different styles of learning, motivation, and engagement in the learning process [3]. These developments, therefore, require the development of modern pedagogical models and trends to achieve the skills, needs, and preferences of students in the 21 st century.

In particular interest to this present study is the feasibility of using flipped classroom in the teaching and learning process for the EFL University students. The flipped classroom as one of the models that have been introduced through technological techniques or commonly called as multimedia-assisted learning such as video, online books, websites, and learning management systems (LMS) in today's teaching and learning practices which can be reached through electronic devices or media [4], [5]. Multimedia-assisted learning as a tool for the students to find the sources of learning. It combined with the strategy of teaching which is called a flipped classroom model.The flipped classroom has been increasingly regarded as an important model to make the quality of teaching and learning outcomes better so that it is considered as an alternative instructional model for teachers to implement [6]. The use of online materials and sources also should be supported by sufficient various sources. Furthermore, the students' attitude toward autonomous learning is a crucial aspect in determining successful learning by using online sources. The students need to keep their motivation and their other work consistently during the teaching and learning activities.

The purpose of a flipped classroom is to reverse the main stages of teaching and learning including classroom activities and homework [7]. That is to say, students study theoretical material individually through the multimedia learning sources, for instance, the visual of video lectures recorded or downloaded from the internet sites, then, during classroom activities that are devoted to practical tasks.

\section{$2 \quad$ Literature Review}

In educational institutions around the world, the flipped classroom method has become a common pedagogy and has been widely studied in higher education contexts [8], [9]. The lessons are given in advance to the students through online videos in the classroom that uses a flipping method to provide them some times to have their active and problem-solving learning. It is an innovative learning concept that aims to increase students' active learning, collaboration, and scaffolding through a better allocation of teaching time during the learning process [7]. This notes that the time spent at face-to-face classrooms should not be focused on instruction, but that students should instead be provided different learning experiences in interactive activities with their peers and be supported with their teachers [10]. Emerging technology in the context of learning environments and instructional content (e.g., online tutorials or videos) can be used to enable students to study and self-assess before the classroom sessions [11]. This helps teachers to substitute the teachers' teaching by these resources and requires the necessary opportunity to take part in the learning process. 
Multimedia-assisted learning is one of the tools to enhance the students' independent learning in the flipped classroom model. Multimedia resources are essential in delivering the information from the teacher to the students as the solution to refresh the conventional teaching-learning strategy. The process of teaching by using sufficient visual media such as multimedia and various online learning can attract the students' attention and make their learning performance better [12]. The application of multimedia and various online learning sources help the students to comprehend what they learn easily. Thus, by using technology make the learning environment more enjoyable and fun. It is in line with Dale [13] who stated that the students achieve good learning results through the use of online presentation, video, and other sources of online learning. Multimedia learning proposes miscellaneous learning lanes for the students especially in implementing flipped classrooms, offers opportunities, and flexibility for students to manage their time of learning and space.

The implementation of the flipped classroom and the use of multimedia-assisted learning cannot be separated each other. Conducting flipped classroom in the teaching and learning process, the teachers need to enhance students' cooperation and their knowledge through the use of various online sources. The flipped classroom focus more on students centered learning. Then, it should be supported by the students' motivation and responsibility. In the flipped classroom, the students are trained to be independent and autonomous learners. The teachers continuously observing the students' process of learning, giving evaluation and valuable feedback. Garrison and Kanuka [14] stated that the flipped classroom approach "is a combination of face-toface and online learning experiences not a layering of one on top of the other" (p. 99). The flipped classroom approach changes the responsibility of the teacher to the students [7]. The approach helps raise learner autonomy through online video lessons and class activities at school.

It is in line with Holec [15] who observed that today's education is based on more personalized and self-driven learning with the term 'take control of one's own learning'. The students are increasingly expected not only to implement the teacher's instructions but also to understand the curriculum's objectives to identify their own learning goals, prepare and organize their learning and evaluate their success. A new paradigm has been brought toward addressing these challenges and demands emerging the aspects required to encourage the autonomy of learners. The advantages of autonomous learners are expanded in Little [16]: (1) When you reflect on your learning it will be more effective and efficient because the learner is precise and based on what the student needs, (2) When learners are interested in learning, the low motivation problem is solved immediately, and (3) When language learning relies on language usage, it is easier to find efficient and spontaneous contact with learners who are already socially independent.

The crucial part of the students' perception during the implementation of a flipped classroom focusing on the quality of teaching and learning in the classroom. Some researchers investigating the students' perception in the implementation of online learning, and the conclusion that the teachers who implemented online learning in their classroom should also understand students perception during the implementation of online learning [17]. Furthermore, the students' satisfaction during online learning 
having a fundamental part in deciding the success of online learning itself. Pollard [18] found online study using a web 2 portal had a constructive influence for students' in terms of building their motivation and provided a valuable chance for autonomous learning. The study conducted by Wright [19] described that the online learning class should be supported by sufficient exercising in the use of online platforms and how to integrate the tool for online learning must be made available to language professional and sufficient internet quality. This condition really helps the students to stimulate and build their autonomous learning without any serious obstacle. The previous studies also proved that students' autonomy and confidence will appear perfectly when the students have their independent way to learn through online learning. This condition happens because the students are less of tension to immediately respond to the questions. It also gains the benefit that the place for the study is more flexible and the self-management and time arrangement in doing their task fully depends on their own responsibility [20].

As the flipped classroom is interesting to be applied in the teaching and learning process in the classroom, it is required to conduct more research in this area, in both theory and practices, particularly for the EFL University students. Some previous research about the flipped classroom model, it is needed to explore more information about the application of this strategy in relation to the students' motivation and perception during their experience in online learning. Considering these issues, this study aims to offer some understanding into students' perception of learning autonomy toward the application of the flipped classroom. The research question is formulated as follows: How multimedia-assisted learning in a flipped classroom revealed the students' learning autonomy?

\section{Research Method}

This qualitative study was conducted in the reading class of the English education department. In order to gain the appropriate data, observation (pre-classroom and during the classroom), questionnaires, and interviews were implemented in a natural setting. 15 undergraduate students in the fifth semester of the English education department who took a reading class were chosen as the participants of this study. The reading class was taught by using the flipped classroom model. Besides engaging with the in-class activities, the students were also required to get involved in online selflearning activities by reading online materials and other online sources. This study was designed to explore how students perceive the implementation of multimediaassisted learning in a flipped classroom model for their learning to promote their autonomous learning. The students were observed during the implementation of the flipped classroom model and at the end of the semester, the students answered 6 questions in the questionnaire form related to the implementation of the flipped classroom in the teaching and learning process. In order to get brief clarification and information related to the implementation of the flipped classroom model and students' perception of autonomous learning which is taken from some points of the questionnaire, then the semi-structured interview was implemented. It is important for 
the students to determine what they have learned with the flipped model in their classroom.

\section{$4 \quad$ Findings}

Students' autonomy can be seen through their effort and motivation in fulfilling all the requirements given by the teachers during the implementation of the flipped classroom model in the reading class. Autonomous students have high initiatives and motivation in finding the solution from the problems they faced. The students could find and read relevant literature from internet sources, watch the video, discuss with colleagues and consults with teachers. In the implementation of the flipped classroom, the students also showed their high motivation, self-management, commitment in doing the task from the teachers, the students' participation in the discussion, language literacy by writing their report and difficulties found during pre-classroom activity, and also language proficiency that can be seen through their reflective essay and their presentation in front of the class. The indicators of the students' autonomous learning can be seen in Table 1:

Table 1. Factors and indicators influence autonomous learning

\begin{tabular}{|l|l|}
\hline \multicolumn{1}{|c|}{ Factors } & \multicolumn{1}{c|}{ Indicators } \\
\hline Self-management & Always submit the assignments on time and complete all the tasks. \\
\hline Active Participation & $\begin{array}{l}\text { Responding to all the learning sessions actively by giving a comment, posting } \\
\text { the idea in LMS and class presentation, and participating actively in questions } \\
\text { and answers session in all the process of discussion. }\end{array}$ \\
\hline Commitment & $\begin{array}{l}\text { Provide enough time to learn online, do all the instruction given by the } \\
\text { teachers, and attending all the class session (at least 14 meetings in a semester) }\end{array}$ \\
\hline Digital Literacy & Select appropriate sources and include citation sources in all the task \\
\hline Language Proficiency & $\begin{array}{l}\text { Have good writing skills based on reflective essay projects and have good } \\
\text { speaking skills in presenting the task by providing a clear and accurate } \\
\text { opinion. }\end{array}$ \\
\hline
\end{tabular}

From table 1, it can be described that the students' autonomous learning can be categorizing based on the indicators that suitable for the factors relevant to autonomous learning. Mostly the students were actively involved in the flipped classroom model. They do all the instructions given by the teachers. Their cooperative learning was also improved because they have active online learning outside the classroom and also have an active class discussion. The feedback from the teachers is given at the end of the classroom session in every meeting.

The results of observation in the flipped classroom model also described some important points. Firstly, in the pre-activity stages, the students are given the responsibility to read a particular topic decided by the teacher. The learning materials can be accessed through relevant internet sources, videos, and other online media. The flipped method to the classroom has greatly improved student autonomy by learning material at home before getting involved in the class. Students were more confident in the classroom with a video lesson and reading printed materials. Secondly, the 
students were ready with the learning materials, they get involved and participate in the classroom easily. The students with high motivation and self-management completed all the tasks on time and do not find a serious problem in their independent learning. Further, they also participate actively during the teaching-learning process because they have sufficient knowledge through the online sources before they attend the class. Thirdly, the student who found difficulties during the pre-activity discuss and consult actively with the teacher and their colleagues.

In the interview, for example, students explained:

"Through searching online materials from the literature online sources, I can practice the topic outside of the classroom and this exercise allows me more comfortable for class activities and discussions."

"I prepared the topic being discussed in the classroom through the multimedia resources in the form of the video which is shared by the teachers in LMS. I could also watch the video when I wanted, when I slept on my bed or when I woke up in the morning, and also watch the video many times when I did not understand."

"Sure, whenever I watch the videos outside the classroom, I can study it by myself. I will post a question and discuss it with others during the online forum conversation when I don't understand. Such activities allow me confident and ready to participate in the learning."

The flipped classroom model is designed by combining the activity inside and outside of the classroom. The students are encouraged to joining online learning by using multimedia-assisted learning (various online sources and LMS) before they come to the class. The students' preparation related to the topic given by the teachers is conducting through online activity, so the students enjoy the teaching-learning process without any pressure. The flipped classroom activity is designed as shown in the Table 2 .

Table 2. The activity in the flipped classroom

\begin{tabular}{|l|l|}
\hline \multicolumn{1}{|c|}{ Stages of Flipped Classroom } & \multicolumn{1}{c|}{ Activity } \\
\hline $\begin{array}{l}\text { Before class activity } \\
\text { (outside of the class) }\end{array}$ & $\begin{array}{l}\text { Read or learn a particular topic given by the teacher through } \\
\text { multimedia online sources and joining LMS provided by the teacher }\end{array}$ \\
\hline \multirow{5}{*}{ During class activity } & Opening the class, brainstorming (10 minutes) \\
\cline { 2 - 2 } & Practices in pairs (10 minutes) \\
\cline { 2 - 2 } & Students presentation, questions and answer (35 minutes) \\
\cline { 2 - 2 } & Summing up and teacher's feedback (20 minutes) \\
\cline { 2 - 2 } & $\begin{array}{l}\text { Writing the reflective essay project and teacher's explanation about } \\
\text { the next topic (25 minutes) }\end{array}$ \\
\hline
\end{tabular}

From table 2, it can be described that the design of flipped classroom activity brings the students actively in independent learning. Their motivation for learning is also one crucial factor in determining the success of the students in joining a flipped classroom model. During the teaching-learning process in the classroom, the students were actively sharing ideas, problems, comments and questions and the teacher also provide valuable feedback related to the students' difficulties and their questions in completing all the tasks. 
The above activities provide several opportunities for students to cooperate with their peers and teacher in class time depending on the flipped learning environment. This result showed the strong social connections among students in flipping classrooms. This encouraged students to inform each other and share knowledge. Flipped classes have also supported students with poor ability to learn and answer their classmates' questions. The use of relevant online learning sources in the alternating classrooms has been noted in particular by all the interviewees as contributing to their positive experiences with other students during class hours. A constructive response was verbalized and shown by the students:

"During the class activity, we develop cooperation with all the students not only inside the classroom but also conducting during the online session when we have interaction in media online forum."

"I never talk to my friends outside the classroom otherwise; just face-toface are we talking inside the class. I get difficulties to connect with my friend for discussing the assignment."

The multimedia online sources like LMS also designed to make learners more closely associated with each other. It shows that the LMS has been accepted as an engaging, connecting and learning environment for students. The students stated, for instance:

“I can learn my friends' behavior, such as their analytical thoughts, proper or supportive students, through comments and postings even from students on the online media."

"Preferable online sources are a good way for online learning and interaction outside the class. With this web and LMS, every day after class I can communicate with my classmates. I could also know them personally by reading their statements and questions through their comments."

This flipped learning provided 60 minutes of classroom conversation activities. Many students also realized that class activities are very useful for student-centered practices such as English conversation and dialog in a small group. The students noted how the flipped classroom provided valuable time to interact with other students in practicing English writing outside the class and speaking skills during the class discussion.

"We will share our English with others outside of the class and listen to the native speakers on film, learn writing and reading as well as learning new vocabulary."

"With the online application outside the classroom, I may practice English and learn English through my friends and improve my experience of listening, reading, and writing in English. Although I did not speak in English outside of the class, I can be posting my idea and comment in the chat forum. And I feel not worried about making a mistake in my English."

The flipped learning class with the use of various online learning sources and multimedia-assisted learning often improved student-teacher engagement. The engagement was determined not only in class but also outside of class time. The teacher may engage more directly or communicate individually with each student in order to enhance the performance of the student by received immediate feedback. 
Interestingly, the teacher did not stand in class anymore, but she engaged in and assisted in the discussions with the students. They expressed their comfort and enjoyment by having interactive times with their teacher through LMS during and after class. The student mentioned:

"In learning through online activity, I can communicate with the teacher anytime even though not inside the class."

"The posts of my friends really help me better understand the subject. The video tutorials sometimes were unclear so my friends shared more information from other sources."

Finally, by the end of the activity, all the interviewees acknowledged that the classroom assignments gave them an opportunity to assess their progress as well as their peers. It also allowed them to understand the topic at the level of their peers. The student said that he checked regularly if his peers made mistakes in their online interaction. Students may fix their peers' errors, along with their own mistakes, by means of peer assessment. By means of self-assessment, students also stated that compared to others, they could identify their weaknesses.

"I understand my ability level after considering the comments and performance of the students in and outside of the classroom. I realize my skills in the classroom."

In addition to an online assessment, students could also evaluate themselves and their face-to-face meetings. In the class, small group debates provided peer feedback on their work. At the end of each class meeting, the teacher was provided an engaging feedback session. This session enabled the teacher to evaluate the entire activities in the classroom including the practice, group discussion, dialog and online activities, including viewing a video lesson, the use of multimedia, and online discussion. The students have shared their opinion that the teacher could provide immediate feedback outside the classes and throughout class hours. The teacher provided some remarks, explanations, suggestions, and highlights related to the topics discussed for an in-class assessment. The student mentioned:

"The teacher would immediately correct my wrong comment, she would never tell me wrong, and she will always comment and suggest my improvement."

"The teacher asked students to provide input on our class activities prior to the class conclusion and eventually evaluated our practices by presenting remarks, clarifications, recommendations and updates on topics."

The teacher also completed the lesson with an assessment during the face-to-face class session. During a group discussion, it was necessary for the students to write a short reflective essay of the text or resources and to submit it to their teacher within 5 days. The teacher gave a few recommendations and responses to student errors.

Students can learn and appreciate material at their own pace by providing online lessons. They have reported that online sources have become the habit of learning each night before going to bed. Here the online sources including video, website, and LMS group has helped effectively integrate the academic experiences of students including face-to-face class meetings and outside online learning. They also said that 
seeing a video lesson outside the classroom presented them with plenty of time to listen to, compose and take notes in English. For example, the students stated:

"The teacher's video lessons were provided in English and I could learn to listen to my English through watching the video which shares through LMS."

"Through making a note of the video I watched and asking a question about the materials of learning, I might learn English writing."

Moreover, the results of the observation and interview also are supported by the results of the questionnaire that shown $47 \%$ out of 15 students are categorized into the students who have high readiness to joining the flipped classroom model, while the rest $52 \%$ have moderate motivation to joining the flipped classroom model, it means they only joining the flipped classroom model because of the demand from the teachers. $48 \%$ out of 15 students used their smartphone and laptop to find relevant literature from internet sources, accessed relevant video, and searching relevant online books or articles related to the topic given by the teacher. From this condition, $43 \%$ out of 15 students strongly agree that the flipped classroom implemented in the teaching-learning process, because it encourages them to be independent learners with an enjoyable learning atmosphere. They can learn freely without any tension. The more students enjoy the learning atmosphere the more likely they were to be autonomous. Meanwhile, $40 \%$ out of 15 students agree that flipped classroom implemented in the teaching and learning process, but it still need to have detail and clear explanation from the teacher related to the material being discussed. And 17\% out of 15 students were disagree to the implementation of flipped classroom in the teaching and learning process, because they think that the implementation of flipped classroom make them difficult to understand the materials being discussed without the teacher explanation like in face to face class. The also argued that by the implementation of flipped classroom they get difficulty in finding the sources of materials for learning, they prefer to have face to face or conventional teaching learning process. Through the implementation of the flipped classroom in the teaching and learning process, 53\% from 15 students are performing better in their assignments given by the teachers. The students are having higher motivation, initiative, and commitment related to the assignment given by the teachers. They also have high motivation in discussing and consulting their difficulties with their colleagues and teachers. It means that the students have high autonomous learning, and it can be proved from the results of the questionnaire that $73 \%$ from 15 students agree that the flipped classroom encourages and stimulate their autonomy learning. It also supports the results of the questionnaire which describes that $47 \%$ out of 15 students are never found serious difficulty in following the flipped classroom model implemented by the teacher. Futhermore, it can be described that students with high motivation and good self-management are able to complete all the assignments. This is probably because the flipped classroom allows for more independence in learning than the traditional classroom. 


\section{Discussion}

From the previous finding, it can be explained that the knowledge is not only the main goal to reach, but how to learn is another important thing they should know [21]. This condition was also supported by Kanelopoulos, Papanikolaou, and Zalimidis [22] who explained that the perspective of the flipped classroom method promotes students' effective participation in the classroom and increases the students' selfconfidence. The students were actively preparing the learning material before attending the class, and also actively participating in the activities on solving some problems in the class.

The first topic discusses the performance of learning which was measured in the classroom through students' experiences. The involvement of the student is quite satisfactory, as the flipped model suggested in this study verified its performance. It is probably due to the learning processes that appropriate with the students' background of study. Before they attended the class, the students started with a preview of online lessons which helped them to understand and recognize difficult concepts. They got a summary of the topics as they took part in the course. The peer interaction approach was then used during face-to-face sessions to encourage the active engagement of students and deeper understanding through group discussion and in-class activities. Throughout presentations and discussions, you should take advantage of the information. Instead, the post-class process has helped them extend their previous knowledge. The teacher could measure their performance in order to see how much they might benefit from this method. The results were similar to previous studies in which students enhanced their performance in the flipped classroom [23].

The flipped classroom combines the use of collaborative technologies with traditional teaching techniques, which improve the influence over students' own learning and encourage further experiences and cognitive involvement. The teacher in teaching lessons utilizes multimedia-assisted learning includes LMS and various online sources as the technology tool for her process. The results showed that students are pleased with their benefits and effectiveness. It is likely because the students found the material easy to understand. Furthermore, they could share content, talk about topical issues and ask questions quite quickly with the features of the tools which encouraged shared learning. Communication among peers and teachers that arise during class at their convenience. The results show that students were pleased with the LMS as equivalent to previous ones [24], [25]. It is supported by Yao [26] who stated that online learning will help in forming learning teams guided by the teacher to establish an effective and efficient learning environment by improving the students' interaction and cooperation.

Focusing on students' comments on the flipped classroom, the students feel enjoy in the implementation of the flipped classroom model in the teaching and learning process. They thought that they were gaining many advantages. The flip-class environment encouraged better engagement, communication, and cooperation among the students and the teacher. The findings were aligned with many previous studies that suggested the encouragement of self-regulating learning environments, class 
engagement and peer participation [23], [27], [28]. Positive results have also shown that both online assignments and classroom activities can be managed.

The last discussion was about the expectations of autonomy which developed after the procedure. This may be because the flipped classroom enables further learning autonomy than the traditional method. In the implementation of this model, knowledge is not just the main goal, it is important to know how to learn. We had more chances to handle themselves. It is possible to conclude the students tend to have more independent learning responsibilities. Although this is their first experience in the flipping classroom they adapt easily and look happy with it. This finding was compatible with other studies in literature review which seem to demonstrate that after the flipped classrooms the students acquired the level of autonomy [29], [30].

Autonomous learning before class, the teacher divides the instructional contents into several small tasks, each containing new points of information. The teacher offers an online material in advance, shares to the students on the LMS and applies the autonomous learning task which the students will write short reflective essays or relevant papers to the material, helps them to understand the problems and key issues so that students can verify if they have mastered the information points or not. Appropriate teaching technique and multimedia should consist of media such as online books, YouTube, and LMS to develop online learning that can enhance the students' communication and collaboration skills. [31]. Simultaneously, students are asked to recognize related or relevant ideas in Indonesia in order to facilitate communication and sharing between teachers and students.

The teacher determines the teaching goal and offers students' opportunity for autonomous learning results, according to the content feedback of the autonomous learning phase before the class. Students participate actively in classroom activities, inform autonomous learning outcomes before lessons, and things that they cannot solve. Presentations including lectures, role play, competitions, discussions, etc. may also be as diverse as possible. According to the autonomous learning report, teachers identify shortcomings and offer solutions to enhance students' curiosity in learning and explore them. The students' oral performance should be enhanced and the use of English should be strengthened in the classroom. Student discussions and collaborative experimentation will solve the problems that students do not solve before class. The teachers can make a comprehensive evaluation and summary, point out problems in learning to new information by students and promote internalization of students' knowledge according to students' attitudes, learning ability and learning style.

Autonomous learning after the class, students can learn individually from different information sources and master main points of knowledge with the aid of a range of digital network equipment by streaming video, learning time, material and location. The teachers can lead students to explore and think consciously about the issues encountered during the learning process so that they can learn how to analyze and finding the solution for their obstacles. In the meantime, the teacher offers timely instruction, meaningful and supportive feedback for the students, in order to promote autonomous learning through different forms of online collaboration with students. 


\section{Conclusion}

Flipping the classroom that integrated the use of multimedia-assisted learning methods is an alternative to potential English courses as it is a worthy learning experience for students. The students' positive feedback indicates they are open to new things. This way of learning helps the students to monitor their education better. Teachers might need to choose the model that serves the context and supporting objectives of the class to make the teaching more beneficial and meaningful. The materials from video is an important part in the implementation of flipped classroom because they help students learn the content and understand the right concept of the lesson. The development of videos is thus a time-consuming part; teachers should have enough time to complete assignments and allow other teachers to reflect before the course begins. Both learner interactions and language performance should be enhanced in classroom practices. Besides that, it is necessary to select a learning platform. The use of efficient technology must be reviewed prior to use because it helps facilitate outside-class engagement amongst students and teachers.

Therefore, we may draw the following referential conclusions that flipped classrooms can be successfully encourage the development of autonomous learning abilities, improve the performance of English, and help to develop the potential of students' collaboration and creativity. Under the flipped classroom model, students' enthusiasm for knowledge and creativity is strongly encouraged, and they are more relaxed and get a challenging learning experience. The new learning model makes students more comfortable in English learning. Flipping teaching helps students to develop an understanding of autonomous learning and promotes enthusiasm for learning.The more students feel satisfied with their learning atmosphere, the more they will increased their autonomous learning.

\section{$7 \quad$ References}

[1] J. Keengwe and D. Georgina, "The Digital Course Training Workshop for Online Learning and Teaching," Educ. Inf. Technol., vol. 17, no. 4, pp. 365-379, 2012. https://doi.org/10.10 07/s10639-011-9164-X

[2] H. El-Ghayalini and N. El-Khalili, "An Approach to Designing and Evaluating Blended Courses,” Educ. Inf. Technol., vol. 17, no. 4, pp. 417-430, 2012. https://doi.org/10.1007/s1 0639-011-9167-7

[3] G. J. Hwang, L. Y. Chiu, and C. H. Chen, "A Contextual Game-based Learning Approach to Improving Students' Inquiry-based Performance in Social Studies Courses," Comput. Educ., vol. 81, pp. 13-25, 2015. https://doi.org/10.1016/i.compedu.2014.09.006

[4] J. Nouri, "The Flipped Classroom: For Active, Effective and Increased Learning especially for Low Achievers,” Int. J. Educ. Technol. High. Educ., vol. 13, no. 1, pp. 1-10, 2016. https://doi.org/10.1186/s41239-016-0032-z

[5] T. Suranakkharin, "Using the Flipped Model to Foster Thai Learners' Second Language Collocation Knowledge," 3L Southeast Asian J. English Lang. Stud., vol. 23, no. 3, pp. 120, 2017. http://doi.org/10.17576/3L-2017-2303-01 
[6] Y. Arifani, S. Asari, K. Anwar, and L. Budianto, "Individual or Collaborative Whatsapp Learning? A Flipped Classroom Model of EFL Writing Instruction," The Journal of Teaching English with Technology, 2020. [Online]. Available: https://www.tewtjournal .org/volume-20/volume-20-issue-1/ . [Accessed: 12-Sep-2019].

[7] J. Bergmann and A. Sams, Flip Your Classroom: Reach Every Student in Every Class Every Day. Arlington: ISTE, 2012. https://doi.org/10.1111/teth.12165

[8] J. Bishop and M. Verleger, "The Flipped Classroom: A Survey of the Research," in 120th ASEE National Conference and Exposition, Atlanta, GA (Paper ID 6219), 2013. https:// doi.org/10.18260/1-2--22585

[9] Z. Zainuddin and S. H. Halili, "Flipped Classroom Research and Trends from Different Fields of Study,” Int. Rev. Res. Open Distance Learn., vol. 17, no. 3, pp. 313-340, 2016. https://doi.org/10.19173/irrodl.v17i3.2274

[10] S. J. DeLozier and M. G. Rodhes, "Flipped Classroom: A Review of Key Ideas and Recommendations for Practice,” Educ. Psychol. Rev., vol. 29, pp. 141-151, 2017. https:// doi.org/10.1007/s10648-015-9356-9

[11] Y. Chen, Y. Wang, Kinshuk, and N. S. Chen, "Is Flip Enough? or Should We Use the Flipped Model Instead?," Comput. Educ., vol. 79, pp. 16-27, 2014. https://doi.org/10.10 16/j.compedu.2014.07.004

[12] M. Lou, "Design of English Multimedia Teaching System Based on Diversification Theory,” Int. J. Emerg. Technol. Learn., vol. 12, no. 1, pp. 119-129, 2017. https://doi.org/ 10.3991/ijet.v12i01.6488

[13] E. Dale, Audio-Visual Methods in Teaching. New York, NY: Holt, Rinehart, \& Winston, 1946.

[14] D. R. Garrison and H. Kanuka, "Blended Learning: Uncovering its Transformative Potential in Higher Education,” Internet High. Educ., vol. 7, pp. 95-105, 2004. https://doi. org/10.1016/j.iheduc.2004.02.001

[15] H. Holec, Autonomy in Foreign Language Learning. Oxford: Pergamon, 1981.

[16] D. Little, "Learner Autonomy and Second/Foreign Language Learning," LLAS Centre for Language, Linguistics, and Area Studies, 2014. [Online]. Available: https://www.llas .ac.uk/resources/gpg/1409\#ref10 . [Accessed: 03-Nov-2019].

[17] P. Ginns and R. Ellis, "Quality in Blended Learning: Exploring the Relationship between Online and Face-to Face Teaching and Learning," Internet High. Educ., vol. 10, pp. 53-64, 2007. https://doi.org/10.1016/j.iheduc.2006.10.003

[18] A. Pollard, "Web-Based Journals in the Classroom: Motivation and Autonomous Learning,” Indones. J. Appl. Linguist., vol. 4, no. 2, pp. 20-31, 2015. https://doi.org/10.17 509/ijal.v4i2.680

[19] B. M. Wright, "Blended Learnings Student Perception of Face-to-Face and Online EFL Lessons," Indones. J. Appl. Linguist., vol. 7, no. 1, pp. 64-71, 2017. https://doi.org/10.17 509/ijal.v7i1.6859

[20] M. K. Tallent-Runnels et al., "Teaching Course Online: A Review of the Research," Rev. Educ. Res., vol. 76, no. 1, pp. 93-135, 2006. https://doi.org/10.3102\%2F00346543076001 $\underline{093}$

[21] B. Santikarn and S. Wichadee, "Flipping the Classroom for English Language Learners: A Study of Learning Performance and Perceptions," Int. J. Emerg. Technol. Learn., vol. 13, no. 9, pp. 123-135, 2018. https://doi.org/10.3991/ijet.v13i09.7792

[22] J. Kanelopoulos, K. A. Papanikolaou, and P. Zalimidis, "Flipping the Classroom to Increase Students' Engagement and Interaction in a Mechanical Engineering Course on Machine Design," Int. J. Eng. Pedagog., vol. 7, no. 4, pp. 19-34, 2017. https://doi.org/10. 3991/ijep.v7i4.7427 
[23] H. T. Hung, "Flipping the Classroom for English Language Learners to Foster Active Learning," Comput. Assist. Lang. Learn., vol. 28, no. 1, pp. 81-96, 2015. https://doi.org/ $\underline{10.1080 / 09588221.2014 .967701}$

[24] K. Balasubramanian, V. Jaykumar, and L. N. Fukey, "A Study on 'Student Preference towards the Use of Edmodo as a Learning Platform to Create Responsible Learning Environment,"” Procedia - Soc. Behav. Sci., vol. 144, pp. 416-422, 2014. https://doi. org/10.1016/j.sbspro.2014.07.311

[25] S. Wichadee, "A Development of the Blended Learning Model using Edmodo for Maximizing Students' Oral Proficiency and Motivation,” Int. J. Emerg. Technol. Learn., vol. 12, no. 2, pp. 137-154, 2017. https://doi.org/10.3991/ijet.v12i02.6324

[26] S. Yao, "Research on Web-based Autonomous English Learning of Engineering Students," Int. J. Emerg. Technol. Learn., vol. 11, no. 6, pp. 4-9, 2016. https://doi.org/10.3991/ijet. v11i06.5802

[27] J. D. Tune, M. Sturek, and D. P. Basile, "Flipped Classroom Model Improves Graduate Student Performance in Cardiovascular, Respiratory, and Renal Physiology," Am. J. Physiol. - Adv. Physiol. Educ., vol. 37, no. 4, pp. 316-320, 2013. https://doi.org/10.1152/a dvan.00091.2013

[28] J. Moffett and A. Mill, "Evaluation of the Flipped Classroom Approach in a Veterinary Professional Skills Course,” Adv. Med. Educ. Pract., vol. 5, pp. 415-425, 2014. https://doi. org/10.2147/amep.s70160

[29] P. Benson and P. Voller, Autonomy and Independence in Language Learning. London: Routledge, 2014. https://doi.org/10.4324/9781315842172

[30] Z. Zainuddin and C. J. Perera, "Exploring Students' Competence, Autonomy and Relatedness in the Flipped Classroom Pedagogical Model," J. Furth. High. Educ., vol. 43, no. 1, pp. 115-126, 2019. https://doi.org/10.1080/0309877X.2017.1356916

[31] J. Khlaisang and K. Mingsiritham, "Engaging Virtual Learning Environment System to Enhance Communication and Collaboration Skills among ASEAN Higher Education Learners," Int. J. Emerg. Technol. Learn., vol. 11, no. 4, pp. 103-113, 2016. https://doi. org/10.3991/ijet.v11i04.5503

\section{Authors}

Eko Aprianto is a doctorate student of Graduate Program in Language and Literature Education of Universitas Negeri Surabaya.

Oikurema Purwati and Syafi'ul Anam are the researcher and an English lecturer at the English Language Teaching Department and Graduate Program in Language and Literature Education of Universitas Negeri Surabaya, Indonesia.

Article submitted 2020-03-01. Resubmitted 2020-07-26. Final acceptance 2020-08-22. Final version published as submitted by the authors. 